\title{
EFFECT OF DIFFERENT CONCENTRATION OF HUMIC ACID ON VEGETATIVE GROWTH AND GREEN PODS ON TWO CULTIVARS OF PEAS( Pisum sativum L.)
}

\author{
ABDUl JebBar IHSAN SAEID* \\ Dept. of Horticulture, College of Agriculture, University of Duhok, Kurdistan Region- Iraq
}

(Received: February 12, 2018; Accepted for publication: June 11, 2018)

\begin{abstract}
The study was carried out during 2017 at the College of Agriculture, University of Duhok, Kurdistan region, Iraq, to study the effects of humic acid on the growth of two peas ( cv. Wolar and Izolda) on growth and green pods yield of Pea plant, were grown in plastic bags. Results showed that cv. (Izolda) gave highest yield/plant (21.58g/plant), compared with cv.Wolar $(17.76 \mathrm{~g} / \mathrm{plant})$. Total green pods was from cv.Izolda which gave142.98 g/plant at level of $18 \mathrm{ml} / \mathrm{l}$ of Humic acid compared with $\mathrm{cv}$. Wolar (131.33g/plant) table (6). The interactions between Izolda and Humic acid at level $\left(18 \mathrm{ml} / \mathrm{L}^{-1}\right)$ gave the best green pods yield $(137.15 \mathrm{~g})$ compared with control $(\mathbf{9 2 . 5 6 g})$.
\end{abstract}

KEY WORD: Humic acid, pea cultivars, green pods,.

\section{INTRODUCTION}

$\mathbf{P}$ ea (Pisum sativum L.) is a one of the most vital plants that belong to the Fabaceae family amongst the most critical and mainstream harvest of leguminoase family developed and growth in Iraq and numerous nations everywhere throughout the world. Pea originates from the Mediterranean and India .It contains numerous nutritional values like high content of protein, phosphorus, carbohydrates, irons, calcium and vitamins A and B (Hassan, 1997). Peas help settle the nitrogen levels in the soil. The territory of planted legumenosae plant was roughly $12-15 \%$ from the region of earth, the world production of pea was $27 \%$ from the seeds of the world (Vance $e t$ al., 2000). The area planted In Iraq is 900 donum that create $15584.4 \mathrm{~kg}$., and the total yield was 1500 ton (Statistic Organization. 2012).

The use of Humic acids has a several advantages and agriculturists everywhere throughout the world are tolerating Humic acids as an essential piece of their compost program. It can be connected specifically to the plant foliage in fluid frame the soil or as granules alone or as manure blend. Humic corrosive is one of the significant parts of humus. Humates are common natural substances, high in humic destructive and containing the vast majority of known follow minerals important to the development of vegetation.

To improve the organic contents of soils for organic crops there are some applications like planting rotation, numerous plough techniques, green fertilizer application and animal manure application. In addition to these practices, utilization of organic-mineral fertilizers in agriculture has increased in recent years (Doran, 2003). Humic acids have been shown to stimulate plant growth and therefore yield by acting on mechanisms involved in: cell respiration, photosynthesis, protein synthesis, water and nutrient uptake, enzyme activities (; Albuzio, 1986; Chen and Aviad, 1990;). One of the used organic -mineral fertilizers is humic acid, (Anonymous, 2010). Under water stress, foliar fertilization with humic molecules increased leaf water retention and the photosynthetic and antioxidant metabolism (Fu Jiu, 1995).Adani, (2006) showed that all humic substances are composed for chemically complex, non-biological organic components, which are largely hydrophilic, dark coloured fluid, or powder and resistant to chemical and biological degradation. Improvement of soil circumstances and establishing equilibrium among plant nutrients are likewise important for soil productivity and plant production .Studies of the effects of humic 
substances on plant gowth, showed improved effects on growth, independent of nutrition (Chen and Aviad, 1990; Dursun, 1999).

Organic fertilizers which include humic materials are one of the natural amendments which are applied to increase the rate of organic matter in the soil related to improving the physical, chemical and biological properties of the soil and therefore improve the plant growth and development (Suganya and Sivasamy, 2006)

Humic acid is a commercial product that has many elements which advance the soil fertility and increase the availability of nutrients and thus increased plant growth and yield. Humic acid is particularly used to ameliorate or reduce the negative effects of chemical fertilizers and some soil chemicals. Many investigators have reported that humic application led to a noteworthy increase in oil of the organic matter improving plant growth and crop production (Hafez and Mejda, 2003)

Humic acid application promotes root growth and increase cell elongation in pea seedlings (Hartwigsen and Evans,, 200) Kaya et al (2005) reported spraying snap bean plants (Phaseolus vulgaris L.) at three - six leaf stage significantly increased plant growth. Zaky et al. (2006) reported that application of humate acid ether as a foliar or injection application ( at $50 \mathrm{~g} / \mathrm{m} 3$ trough the irrigation water, gave a noteworthy increase in the entire chlorophyll of the pods of the common bean plants(phaseolus vulgaris L.)

The increase in number and height of leaves as organic mineral rates increased confirmed the role of organic minerals in endorsing vital vegetative growth in fruits of melons and tomato (Olaniyiet al., 2006; Olaniyi and Ajibola, 2008)

Patillet al. (2010) carried out a plot experiments to show the effects of potassium humate salt of the humic acid of protein consents and vegetative growth of (Phaseolus mungo L.). The results obtained during this investigation clearly indicated that the plant treated with potassium humate show significant increase on vegetative growth characters and protein contents than control plants.

\section{MATERIALS AND METHOD}

The experiment was carried out on 22 February, to 25 June 2017 on research farm, college of Agriculture, University of Duhok. Seeds were planted in black plastic bags $\left(21.5 \mathrm{~cm}^{2}\right.$ diameters). Combination of soil and animal manure was used (1:2). As temperature increased, the soil was put around the black plastic bags to reduce the hug temperature effects on roots. Two factors in randomized Complete Block Design (RCBD) was used with 3 replications, the first factors was humic acid at four levels $(0,6,12$ and $\left.18 \mathrm{ml} / \mathrm{L}^{-1}\right)$,- the second was two pea cultivars from Poland ( (Walor) and (Izolda), so the experiment consist of 8 treatments $(2 * 4)$. Humic acid added three times at 15 days intervals. First adding was after plant reaching five leaves, second was after 15 days of the first and third adding after 15 days of second one. The data were analysed by using SAS program. The experimental traits were(plant length $(\mathrm{cm})$, branch number, stem diameter $(\mathrm{mm})$ and fresh weight (g/plant) and quality characteristic of pea, that include: pods weight (gm), number of seed/ pod , , pods number/plant, pods length, and green yield of pea ,that include: early and total green pods yield as describe by [Al-Ashraf.(1989)].

\section{RESULTS AND DISCUSSION}

Table (1) shows the data regarding the number of branch/plant Indicates significant differences between cultivars, the maximum number obtained from ( Izolda) cultivar (4.15)compared with (Valor) cultivar (4.05, at level of $\left(18 \mathrm{ml} / \mathrm{L}^{-1}\right)$ humic acid recorded the highest value of branches number (4.67)which was different significantly from other concentration especially the control. Concerning the fresh weight of pea shows that cultivar ( Izolda) gave a significant increase in fresh weight which reached $(52.33 \mathrm{gm})$ in cultivar (Izolda) compared with ( walor ) cultivar that 
Table ( 1 ): Effect of different concentration of Humic Acid on Branches number and fresh weight (g) on two Peas cultivars and their interaction Means followed by different letters were significantly different based on Duncan's Multiple 5\%

\begin{tabular}{|c|c|c|c|c|c|c|c|c|c|c|}
\hline \multirow[t]{3}{*}{ Cultivars } & \multicolumn{4}{|c|}{ Branch number.plant- ${ }^{1}$} & \multirow{3}{*}{$\begin{array}{l}\text { Effect of } \\
\text { cultivars }\end{array}$} & \multicolumn{4}{|c|}{ Fresh weight(gm) } & \multirow{3}{*}{$\begin{array}{l}\text { Effect of } \\
\text { cultivars }\end{array}$} \\
\hline & \multicolumn{4}{|c|}{ humic acid (ml.L-1) } & & \multicolumn{4}{|c|}{ humic acid (ml.L-1) } & \\
\hline & 0 & 6 & 12 & 18 & & 0 & 6 & 12 & 18 & \\
\hline Valor & $3.54 \mathrm{c}$ & $4.11 b$ & $4.00 \mathrm{~b}$ & $4.55 a$ & $4.05 b$ & $36.30 d$ & $56.37 \mathrm{~b}$ & $48.50 \mathrm{c}$ & $48.20 \mathrm{c}$ & $38.03 b$ \\
\hline Izolda & $3.30 d$ & 4.33ab & $4.33 a b$ & $4.67 a$ & $4.15 a$ & $36.80 d$ & $55.22 a b$ & $58.44 a$ & $58.88 a$ & $52.33 a$ \\
\hline Effect of H.A & $3.42 \mathrm{c}$ & $4.22 \mathrm{~b}$ & $4.16 \mathrm{~b}$ & $4.61 \mathrm{a}$ & & $36.55 c$ & $55.74 a$ & $53.47 a$ & $53.54 b$ & \\
\hline
\end{tabular}

gave lower value of fresh weight $(38.03 \mathrm{gm})$.The interaction between cultivar and application of Humic acid, remarked significant deference amid concentration of Humic acid, best result obtain at level of $6 \mathrm{ml} / \mathrm{L}^{-1} 55.74$ g, compared with control, significant increase in stem diameter as a result of the humic acid concentration that significantly.

In the same time there was differed compared to untreated plant which gave poorer weight of plant (36.55g).Concerning the interaction among treatments there were significant increase among treatments the highest weight of plant were when plant treated with $\left(12 \mathrm{ml} / \mathrm{L}^{-1}\right)$ humic acid with cultivar (Izolda) that gave $(58.44 \mathrm{gm})$ as compared with other interactions specially untreated interaction with humic acid in both cultivars that gave lower weight (36.3 respective $36.8 \mathrm{~g})$.

Data in Table (2) show significant difference between cultivars (Izolda) cultivar gave $(42.91 \mathrm{~cm})$ compared with (Walor) cultivar $(36 \mathrm{~cm})$ regarding plant high. The interaction among cultivars and concentration of Humic acid remarked at cultivar (Izolda) $53.97 \mathrm{~cm}$ at level of $\left(12 \mathrm{ml} / \mathrm{L}^{-1}\right)$ compared by control $(22.67 .67 \mathrm{~cm})$

Concerning the effect of cultivars on stem diameter remarked cultivar (Izolda) raised significant $(4.00 \mathrm{~mm})$ over cultivar (Wolar) by ( $17.98 \%$ ) 
Table (2): Effect of different concentration of Humic Acid on stem diameter(mm) and plant height on two Peas cultivars and their interaction Means followed by different letters were significantly different based on

Duncan's Multiple 5\%

\begin{tabular}{|c|c|c|c|c|c|c|c|c|c|c|}
\hline \multirow[t]{3}{*}{ Cultivars } & \multicolumn{4}{|c|}{ Stem diameter $(\mathrm{mm})$} & \multirow{3}{*}{$\begin{array}{l}\text { Effect of } \\
\text { cultivars }\end{array}$} & \multicolumn{4}{|c|}{ Plant length (cm) } & \multirow{3}{*}{$\begin{array}{l}\text { Effect of } \\
\text { cultivars }\end{array}$} \\
\hline & \multicolumn{4}{|c|}{ humic acid (ml.L-1) } & & humic a & $(\mathrm{ml} . \mathrm{L}-1)$ & & & \\
\hline & 0 & 6 & 12 & 18 & & 0 & 6 & 12 & 18 & \\
\hline Walor & $2.33 d$ & $3.68 b$ & $4.11 \mathrm{a}$ & $4.00 a b$ & $3.53 b$ & $22.67 d$ & $41.00 \mathrm{bc}$ & $34.00 \mathrm{c}$ & $46.33 b$ & $36.00 \mathrm{~b}$ \\
\hline Izolda & $3.67 c$ & $4.33 a$ & $4.00 \mathrm{a}$ & $4.00 \mathrm{ab}$ & $4.00 \mathrm{a}$ & $23.67 c$ & $50.67 a$ & $53.97 a$ & $44.33 b$ & $42.91 \mathrm{a}$ \\
\hline $\begin{array}{l}\text { effect } \\
\text { of H.A }\end{array}$ & $3.00 \mathrm{c}$ & $4.00 \mathrm{a}$ & $4.17 a$ & $4.00 \mathrm{~b}$ & & $23.17 b$ & $45.83 a$ & $43.98 a$ & $45.33 a$ & \\
\hline
\end{tabular}

Regarding the effect of interaction between cultivars and level of humic acid, showed significant differences between (Walor) and (Izolds) cultivars, ( Izolda ) significantly increased reaching (4.33mm) compared with (2.33 $\mathrm{mm})$ in ( Walor ) cultivar.

Table (3): Shows the effect of Humic acid on leaves area of two peas cultivar, the cultivar (Izolda) caused a significant increase $\left(3.00 \mathrm{~cm}^{2}\right)$ compared with cultivar(Walor) $2.66 \mathrm{~cm}^{2}$. The interaction between cultivars and Humic acid cause significant effect at rate of $6 \mathrm{ml} / /^{-1}$ (Izlods) cultivar $\left(4.33 \mathrm{~cm}^{2}\right)$ compared by untreated $2.33 \mathrm{ml} / \mathrm{L}^{-1}$

\begin{tabular}{|c|c|c|c|c|c|c|c|c|c|c|}
\hline \multirow[t]{3}{*}{ Cultivars } & \multicolumn{4}{|c|}{ Leaf area $(\mathrm{cm})$} & \multirow{3}{*}{$\begin{array}{l}\text { Effect of } \\
\text { cultivars }\end{array}$} & \multicolumn{4}{|c|}{ Chlorophyll (SPAD) } & \multirow{3}{*}{$\begin{array}{l}\text { Effect of } \\
\text { cultivars }\end{array}$} \\
\hline & \multicolumn{4}{|c|}{ humic acid (ml.L-1) } & & \multicolumn{4}{|c|}{ humic acid (ml.L-1) } & \\
\hline & 0 & 6 & 12 & 18 & & 0 & 6 & 12 & 18 & \\
\hline Walor & $2.33 d$ & $3.68 b$ & $4.11 \mathrm{a}$ & $4.00 \mathrm{ab}$ & $2.66 b$ & $33.30 \mathrm{c}$ & $41.83 b$ & $40.22 b$ & $40.12 \mathrm{ab}$ & $37.90 \mathrm{~b}$ \\
\hline Izolda & $3.67 c$ & $4.33 a$ & $4.00 a$ & $4.00 \mathrm{ab}$ & 3.00.a & $33.13 c$ & $45.6 a b$ & $48.78 a$ & $40.13 b$ & $41.91 \mathrm{a}$ \\
\hline Effect of & 3.00 & 4.00 & 4.17 & 4.00 & & 33.28 & 43.71 & 44.50 & 40.12 & \\
\hline H.A & C & a & A & $\mathrm{b}$ & & $c$ & $\mathrm{a}$ & $\mathrm{a}$ & $\mathrm{b}$ & \\
\hline
\end{tabular}

The same table shows the effect of Humic acid on chlorophyll\% in leaves, concerning the chlorophyll content; the best result was obtained in cultivar (Izolda.) 41.91 compared with cultivar (Walor) 37.90. Regarding the interaction between cultivars and Humic acid concentration, observed significant increasing in cultivar (Izolda) at $12 \mathrm{ml} / \mathrm{l}$ Humic 48.78 compared by untreated 33.13 , increasing by $47.23 \%$ about the chlorophyll content.

Data illustrated at Table (4) shows that there are noteworthy differences between cultivars regarding the seed number/pod with (Izolda) cultivar ( 6.53), in cultivar (Walor 6.07) increasing by $7.57 \%$

Regarding the effect of cultivars on pods length, observer the cultivar

(Izolda) was significant different over cultivar (Walor) $7.28 \mathrm{~cm} 6.00 \mathrm{~cm}$

respectively.

About the interaction between cultivar and Humic acid which caused a significant increase in seed number at rate $12 \mathrm{ml} / \mathrm{L}^{-1}$ of.7.00 in cultivar (Izloda) compared with cv.Walor control 5.23 rises 
Table (4): Effect of different concentration of Humic Acid on seed number/pod and pods length(cm) on two Pea cultivars and their interaction Means followed by different letters were significantly different based on Duncan's Multiple 5\%

\begin{tabular}{|c|c|c|c|c|c|c|c|c|c|c|}
\hline \multirow[t]{3}{*}{ Cultivars } & \multicolumn{4}{|c|}{ Seed number.pod-1 } & \multirow{3}{*}{$\begin{array}{l}\text { Effect of } \\
\text { cultivars }\end{array}$} & \multicolumn{4}{|c|}{ Pods length (cm) } & \multirow{3}{*}{$\begin{array}{l}\text { Effect of } \\
\text { cultivars }\end{array}$} \\
\hline & \multicolumn{4}{|c|}{ humic acid (ml.L-1) } & & \multicolumn{4}{|c|}{ humic acid (ml.L-1) } & \\
\hline & 0 & 6 & 12 & 18 & & 0 & 6 & 12 & 18 & \\
\hline Walor & $5.23 d$ & $6.2 b$ & $6.67 a b$ & $6.2 \mathrm{~b}$ & $6.07 \mathrm{~b}$ & $4.33 c$ & $6.93 b$ & $6.19 \mathrm{bc}$ & $6.8 \mathrm{bc}$ & $6.06 \mathrm{~b}$ \\
\hline Izolda & $5.67 \mathrm{c}$ & 6.68ab & $7.00 \mathrm{a}$ & $6.8 b$ & $6.53 a$ & $6.1 \mathrm{~b}$ & $7 a b$ & 7.53ab & $8.5 \mathrm{a}$ & $7.28 \mathrm{a}$ \\
\hline Effect of H.A & $5.45 c$ & $6.44 b$ & $6.83 a$ & $6.50 a b$ & & $5.21 b$ & $6.96 c$ & $6.86 a b$ & $7.65 a$ & \\
\hline
\end{tabular}

Concerning the interaction between cultivars and level of Humic acid remarked a significant difference at cultivar (Izolda) $8.5 \mathrm{~cm}$ at level of $18 \mathrm{ml} / 1$ compared by $\mathrm{cv}$. Walor control $4.33 \mathrm{~cm}$.

Table (5) show the effect of cultivars on pods weight (g), cultivar (Izolda) gave (2.51g) significant increasing compared with (Walor) cultivar $(1.82 \mathrm{~g})$ riseaning by $39.44 \%$.

Concerning effect of interaction among cultivars and Humic acid on pods weight, at level of $18 \mathrm{ml} / \mathrm{l}$ its significant (2.92)g compared with control (1.88)g rise by $21.80 \%$.

In table (5) regarding the pods number remarked increasing significantly cultivar (Izolda) 11.44 over (Walor) cultivar (10.02) rising by $14.17 \%$.

Concerning the interaction between cultivars and level of Humic acid concentration on pods number showed at level of $18 \mathrm{ml} / 1$ cultivar (Izolda) was significant (13.67) compared with control (9.90) increase with $38.08 \%$.

Table (5): Effect of different concentration of Humic Acid on Wt. of pods(gm) and pods number on two pea cultivars and their interaction Means followed by different letters were significantly different based on Duncan's Multiple 5\%

\begin{tabular}{|c|c|c|c|c|c|c|c|c|c|c|}
\hline \multirow[t]{3}{*}{ Cultivars } & \multicolumn{4}{|c|}{ Wt of pods(gm) } & \multirow{3}{*}{$\begin{array}{l}\text { Effect of } \\
\text { cultivar } \\
\mathrm{S}\end{array}$} & \multicolumn{4}{|c|}{ Pods number } & \multirow{3}{*}{$\begin{array}{l}\text { Effect } \\
\text { cultivars }\end{array}$} \\
\hline & \multicolumn{4}{|c|}{ Humic acid (ml.L-1) } & & \multicolumn{4}{|c|}{ humic acid (ml.L-1) } & \\
\hline & 0 & 6 & 12 & 18 & & 0 & 6 & 12 & 18 & \\
\hline Walor & $1.78 \mathrm{~b}$ & $1.83 \mathrm{~b}$ & $1.45 b$ & $2.25 a$ & $1.82 \mathrm{~b}$ & 8.01d & $11 \mathrm{~b}$ & $10 c$ & $11 . .1 \mathrm{~b}$ & $10.02 b$ \\
\hline Izolda & $1.88 \mathrm{c}$ & $1.74 b$ & $2.73 a$ & $2.92 a$ & $2.51 \mathrm{a}$ & $9.90 \mathrm{~d}$ & $12 b$ & $10.2 \mathrm{c}$ & $13.67 \mathrm{a}$ & $11.44 \mathrm{a}$ \\
\hline effect of H.A & $1.83 \mathrm{c}$ & $1.78 \mathrm{~b}$ & $2.09 a b$ & $2.58 a$ & & $9.65 c$ & $11.5 b$ & $10.1 b$ & $12.38 \mathrm{a}$ & \\
\hline
\end{tabular}

Table (6) showed early and total yield g/plant, the early yield taken from first three harvested. Cultivar (Izolda) caused significant increasing $21.58 \mathrm{~g} /$ plant compared with (Walor) cultivar $17.76 \mathrm{~g} / \mathrm{plant}$.

Concerning the interaction among cultivars and rate of Humic acid on early yield, remarked significant difference in cultivar (Izolda) at level of $12 \mathrm{ml} / \mathrm{L}$ by $23.80 \mathrm{~g} / \mathrm{plant}$, compared with control $15.77 \mathrm{~g}$

In the same table regarding the total yield $\mathrm{g} /$ plant remarked significant increase cultivar Izolda $123.65 \mathrm{~g}$ compared with Walor $109.4 \mathrm{~g}$. 
Table (6): Effect of Humic acids, cultivars and their interactions on early and total green pods yield of pea.

\begin{tabular}{|c|c|c|c|c|c|c|c|c|c|c|}
\hline \multirow[t]{3}{*}{ Cultivars } & \multicolumn{4}{|c|}{ Early yield(gm.plant-1) } & \multirow{3}{*}{$\begin{array}{l}\text { Effect of } \\
\text { cultivars }\end{array}$} & \multicolumn{4}{|c|}{ Total yield (gm.plant-1) } & \multirow{3}{*}{$\begin{array}{l}\text { Effect of } \\
\text { cultivars }\end{array}$} \\
\hline & \multicolumn{4}{|c|}{ humic acid (ml.L-1) } & & \multicolumn{4}{|c|}{ humic acid (ml.L-1) } & \\
\hline & 0 & 6 & 12 & 18 & & 0 & 6 & 12 & 18 & \\
\hline Walor & $15.77 \mathrm{c}$ & $20.00 a b$ & $15.17 \mathrm{~b}$ & $20.12 b$ & $17.76 b$ & $89.80 \mathrm{c}$ & $94.60 \mathrm{c}$ & $122.00 \mathrm{~b}$ & 131.33ab & 109.40 \\
\hline Izolda & $19.70 \mathrm{~b}$ & $22.45 a$ & $23.80 \mathrm{a}$ & $21.58 \mathrm{a}$ & $21.58 \mathrm{a}$ & $95.33 c$ & $115.30 \mathrm{~b}$ & $141.00 \mathrm{a}$ & $142.98 \mathrm{a}$ & $123.65 a$ \\
\hline $\begin{array}{l}\text { effect of } \\
\text { H.A }\end{array}$ & $17.73 \mathrm{c}$ & $21.22 \mathrm{a}$ & $19.48 b$ & $20.26 \mathrm{~b}$ & & $92.56 \mathrm{c}$ & $104.95 b$ & $132.00 \mathrm{ab}$ & $137.15 a$ & \\
\hline
\end{tabular}

Means followed by different letters were significantly different based on Duncan's Multiple 5\%

In table(6) the interaction among cultivars and Humic acid application on total yield(g/plant),cultivar (Izolda) at level of $18 \mathrm{ml} / \mathrm{L}$ caused significant effect on yield $142.98 \mathrm{~g} / \mathrm{plant}$ compared with control, increased by $49.98 \%$.

\section{DISCUSSION}

The effect of cultivars on all parameters(Number of branch, plant length, lives area, chlorophyll content, stem diameter, fresh weight, seeds number/pod, pods length, pods number/plant, early yield, total yield). Remarked significant increasing. The cultivar (Izolads) overcame cultivar (Walor), the increase might be due to the differences in genotype characteristics of the root growth and nutrient absorption and photosynthesis procedure (Jordao, et al, 1999). Also response of cultivars to local environmental state according to the genetic difference among cultivars (Gaafar and Saker, 2006)

Regarding the effect of humic acid on vegetative parameter, studies indicate that concentration of $12 \mathrm{ml} / \mathrm{l}$ of Humic acid gave a significant differences in leaf area, chlorophyll content, early total yield, stem diameter, seeds number/pods. The concentration of $18 \mathrm{ml} / 1$ gave a significant affect in pods length, number of branch and pod $s$ length compared with untraded cultivars. The reason for the positive effect might be due to role of Humic acid to stimulated plant growth, cell respiration, protein synthesis, photosynthesis and enzyme activities(Nardi, et al 1996, Chen et al 2004 and Ali, et al 2007) .

Concerning the interaction between cultivars and level of Humic acid, remarked best result in number of branch at level of $18 \mathrm{ml} / 1$ and fresh weight at rate of $12 \mathrm{ml} / 1$.

In this study cv. Izolda overcame cv. Walor in early and total green pod at level of $12 \mathrm{~m} / 1$ and $18 \mathrm{~m} / 1$ humic acid

\section{REFERENCES}

- ALBUZIO A, FERRARI G and NARDI S. 1986. Effects of humic substances on nitrate uptake and assimilation in barley seedlings. Can J Soil Sci 66, 731-736.

- Anonymous. 2010. Humic and fulvic acids: The black gold of agriculture.htt:// www. humintech.com/pdf/humicfulvicacids.pdf (Access date: 10.08.2010).

- CHEN Y and AVIAD T. 1990. Effects of humic substances on plant growth. In: Humic substances in soil and crop sciences: selected readings (MacCarthy P., Clapp C., Malcolm R.L., Bloom P.R., eds). Am Soc Agron, Madison, WI, USA. pp. 161-186

- Dursun A, Guvenc I and Turan M. 1999. Macro and micro nutrient contents of tomato and eggplant seedlings and their effects on seedling growth in relation to humic acid application. Improved Crop Quality by Nutrient Management. Kluwer Acedemic Publishers Ordrecht. Boston.London.

- Dursun, A.; I. Guvenc and M. Turan. (2002). Effects of different levels of humic acid on seedling growth and macro and micronutrient contents of tomato and eggplant. Acta Agriculture. 56: 8188.

- Doran I, Akinci C and Yildirim M. 2003. Effects of delta humate applied with different doses and methods on yield and yield components of Diyarbakir-81 wheat cultivar. 5th Field Crops Congress, Diyarbakir, Turkey. (2): 530-534 (in Turkish with English abstracts).

- Fu Jiu C, Dao Qi Y and Quing Sheng W. 1995. Physiological effects of humic acid on drought resistance of wheat (in Chinese), Yingyong Shengtai Xuebao 6, 363-367. 
- Hafez, M. Majda. (2003). Effect of some sources of nitrogen fertilizer and concentration of humic acid on the productivity of squash plant. Egypt. J. Appl. Sci; 19(10) 293-309.

- Hartwigsen, J.A. and M.R. Evans. (2000). Humic acid seed and substrate treatment promote seedling root development. Hort. Science. 35 (7):12311233.

- Hassan, A.A., (1997). Vegetable fruits. Al-Dar AlArabia Publications and distribution, Cairo, Egypt, pp: 241.

- Olaniyi, J.O. (2006). Influence of Nitrogen and Phosphorus fertilizers on seed Yield and Quality of 'Egusi' Melon (Citrullus lanatus (Thunb) Mansf.) in Ogbomoso south Western Nigeria. Ph. D Thesis U.I., Ibadan, Nigeria.pp. 210.

- Olaniyi, J.O and A.T. Ajibola. (2008). The effects of inorganic and organic fertilizers application on the growth, fruit yield and quality of tomato (Lycopersicon lycopersicum). Journal of Applied Biosciences. 8(1): 236-242.

- Patill, R.; S. Junne; S. Mokle; S. Wadje. (2010). Effect of Potassium Humate on Vegetative Growth and Protein Contents of Glycine max (L.) Merrill and Phaseolus mungo (L.). Scholars
Research Library. Available online at www.scholarsresearchlibrary.com. 2 (1): 76-79.

- Statistic Iraqi Organization Central for agricultural. (2012).Ministry of production mop/ www.mop.gov.iq.

- Suganya, S. and R. Sivasamy. (2006). Moisture retention and cation exchange capacity of sandy soil as influenced by soil additives. J. Appl. Sci. Res., 2: 949-951

- Vance, C.P., Graham P.H. andAllen D.L. "Biological nitrogen fixation phosphorus"In:A critical future need, FoPedrosa, M.

- Hungria, M.C., Yates and W.E. Newton, eds., Nitrogen fixation from molecules to crop productivity.Kluwer Academic Publishers. Dordercht, The Netherlands, pp. 506-514. (2000).

- Vance, C.P., P.H. Graham and D.L.Allen. (2000). Biological nitrogen fixation phosphorus: A critical future need, in FoPedrosa, M. Hungria, M.C., Yates and W.E. Newton, eds.

- Zaky, M. H.; O.R. El-Zeiny and M.E. Ahmed. (2006). Effects of humic acid on growth and productivity of bean plants grown under plastic low tunnels and open field. Egypt. J. Appl. Sci., 21(4):582-596.

كارتئكرنا خهستيئت ترشئ هيوميك لسهركهسكاتى و كهليكئت كهسك يئت دووجورئت بهز اليا 


\section{(Pisum sativum L.)}

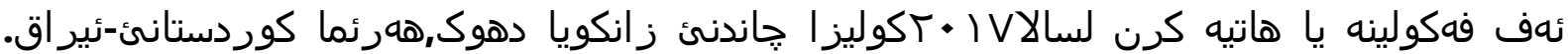

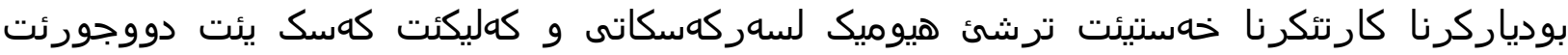

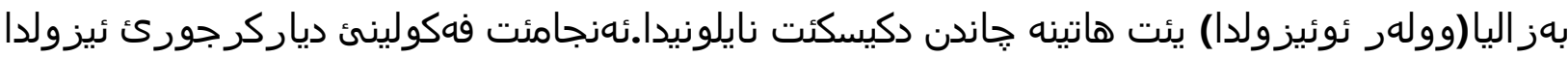

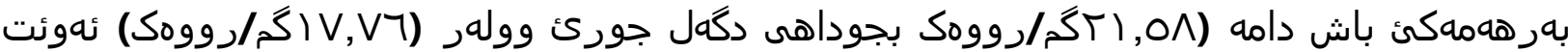

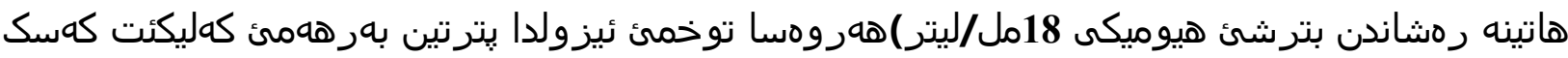

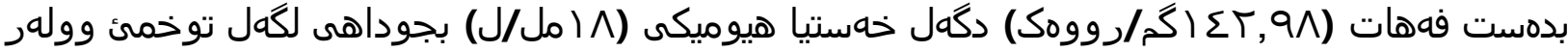

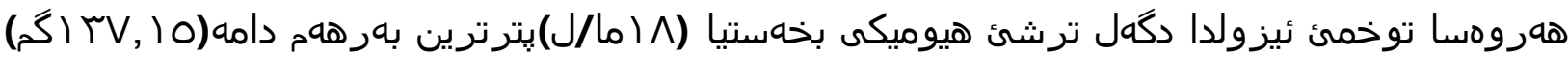
بجودا هى دكَل توخم و خهستيا ديتر.

تأثير تراكيز مختلفه لحامض الهيوميك على الصفات الخضريه و كمية القرون ( Pisum Sativum L) الخضر اء لصنفين من البز اليز لتخديا

أجريت هذه الدراسه في سنة 2017 في حقل الخضراوت التابية التابعه لكلية الزداعه جامعة دهوك أقليم كوردستان العراق لبيان تأثير تراكيز حامض الهيوميك على الصفات الخضريه و كمية القرون الخضراء التراء

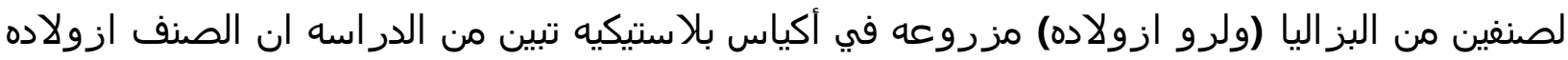

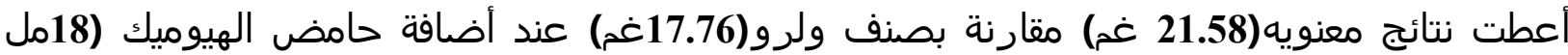

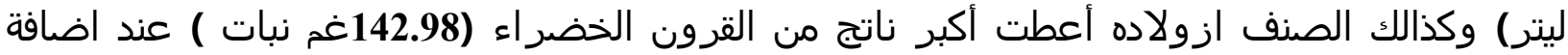
18مل ليتر مقارنة مع الصنف الثاني (137.15غم مقارنة بمعامل المقارنه( 